\title{
Science and Religion in Meta-Perspective - Part I
}

\author{
Herman J. Pietersen \\ Professor, University of Limpopo, Turfloop Campus 0727, Republic of South Africa \\ herman.pietersen@ul.ac.za
}

\section{Doi:10.5901/mjss.2014.v5n20p1969}

\section{Abstract}

\begin{abstract}
A meta-theory was developed that brought together implicit premises or world views that constantly re-surface in human thought. Although these elements, which are often referred to in the literature as the result of differences in human 'temperament', have long been part of the scholarly activity of humankind, a comprehensive synthesis has been lacking so far. In order to redress this shortcoming, an integrated perspective, supported by scholarly evidence, regarding basic characteristics of making sense of life and world is introduced. As a result four paradigmatic or root intellectual orientations (designated as type I, type II, type III and type IV) have been identified. The theory was found to be applicable across a wide range of thinkers, scholarly disciplines, and cultures. In the current paper (Part I) the framework is presented in terms of its main components and dynamics. Against this background the history of the science-religion interrelationship (hereafter also referred to as $S-R$ ) is briefly reviewed. Separate papers deal with objectivist tendencies (Part II), and with subjectivist manifestations in the S-R field (Part III).
\end{abstract}

Keywords: Archetypal modalities, exemplars, history, Zygon movement, objectivist-subjectivist, empyrean-empiricist.

\section{Introduction}

The meta-theory to be utilized here was developed in detail in a first volume (Pietersen, 2011) and continued with new applications in a second volume,(Pietersen, 2014) and will therefore only briefly be discussed.

A fundamental theoretical approach was developed that brought together in a coordinated manner, implicit intellectual premises or world views that constantly re-surface in human thought. Although these elements have long been part of the scholarly activity of humankind, a comprehensive synthesis has been lacking. The present series of papers show that the theory can also be applied to the field of science and religion.

\subsection{Archetypal orientations of the mind}

Figure 1 shows four orientations in human thought that are the result of a combination of two axes (epistemological and ontological), namely: objectivist-empyrean (type I); objectivist-empiricist (type II); subjectivist-empiricist (type III), and the subjectivist-empyrean (type IV).

This is followed in Figures 2, 3, 4 and 5 by a description of characteristic elements of each of the four archetypes. These should be more or less self-explanatory, but it may be helpful to point out that each of the primary orientations address a different and basic question, namely: (a) what is this? (Type II); (b) what is behind this? (Type I); (c) what is wrong / wonderful about this? what is the story? (Type III); (d) what should be done about this? (Type IV).

Figure 1: The four orientations in human thought

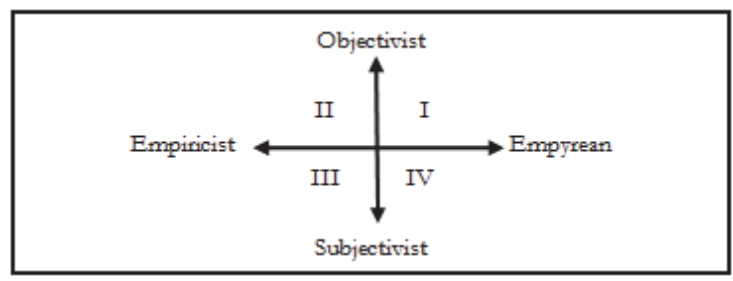


Figure 2: Objectivist-empyrean (type I) elements

\begin{tabular}{ll|} 
Emphasize reason (rationality) \\
Impersonal \\
Theoretical/integrative \\
Macroscopic focus \\
Comprehensive understanding \\
Concerned with possible ideas \\
To penetrate the deepest essentials and mysteries of life/world.
\end{tabular}

Figure 3: Objectivist-empiricist (type II) elements

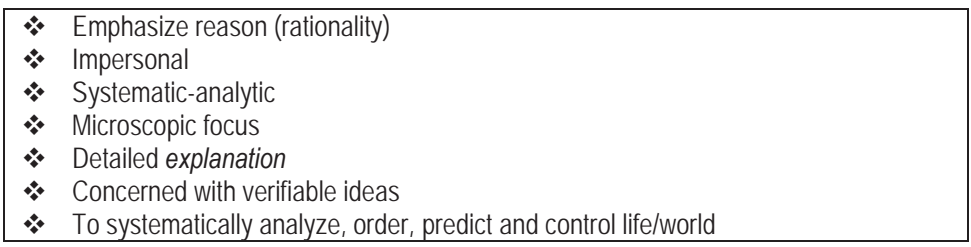

Figure 4: Subjectivist-empiricist (type III) elements

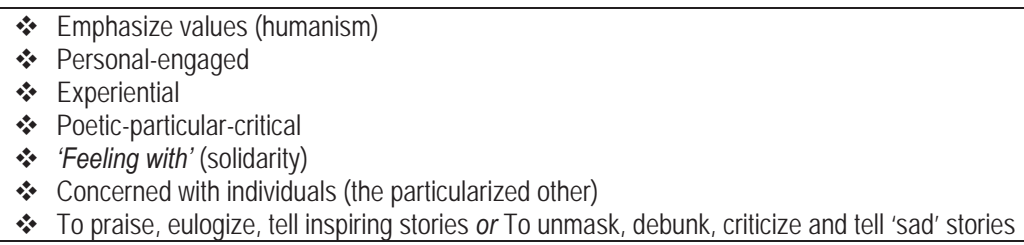

Figure 5: Subjectivist-empyrean (type IV) elements

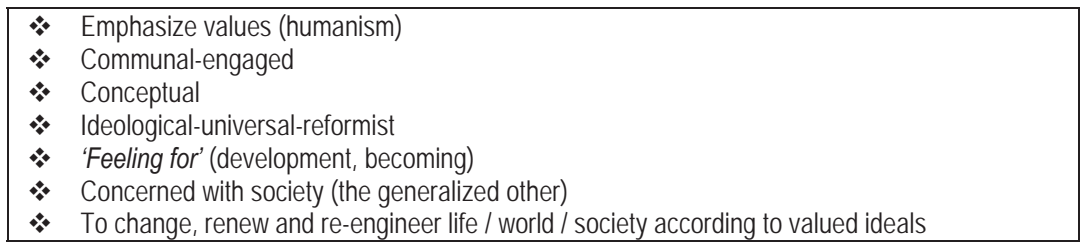

\subsubsection{The main principles}

The main propositions or theses of the meta-theory are as follows (Pietersen, 2011):

Fundamental orientations of mind predetermine the type of ideas, theories, "ways" of making sense of and dealing with the world.

a) Each orientation or modality of mind co-exists with other modes in a dynamic mutuality of conflict and complementariness.

b) Thought products (individually or collectively) reflect different mixes of the basic orientations, although dominant (primary) tendencies prevail as a result of root "preferences". No thinker functions entirely within a single (primary) mode of thought, but also in varying degrees interfaces with directly adjacent (secondary) modes. Tertiary orientations also manifest in each intellectual product, either in a conflicting, suppressed or underrepresented manner.

c) Together, the different modes of thought form a unity or whole with each giving meaning to the other and with each dependent on the existence of its opposite mode.

d) Attempted dominance by one modality of mind inevitably leads to countervailing reactions in other realms of thought. Adherents of highly divergent (directly opposing) orientations will more likely experience mutual 
misunderstanding, disaffection and even potentially irreconcilable beliefs and convictions.

e) Knowledge endeavours in the world at large, in different cultures, disciplines and traditions of thought, and at different levels of analysis, show similarity in terms of underlying modalities of mind.

f) The limitations of one modality of mind are complemented by the strengths of others, especially its diagonally opposite mode.

\subsection{Some exemplars in the history of thought}

In this section a number of representatives of each of the main intellectual types in human thought, in this case in ancient Greek philosophy, Christian theology, modern Western philosophy and, lastly, modern philosophy of science, are introduced (see Pietersen, 2011; Pietersen, 2014). The main reason for doing this is to show the wide-ranging applicability of the meta-theory, in terms of work already carried out in analyzing other areas of scholarship.

\subsubsection{Type l: Plato, Gabirol, Augustine, Descartes and Popper}

(a) Plato: In Western thought, Plato figures as probably the most prominent and prototypical example of an objectivistempyrean thinker. This Greek philosopher produced the first all-round theory of knowing and being, which, inter alia, is presented in his parables of the Divided Line, the Sun and the Cave. Plato undoubtedly had the kind of mind that attempted to achieve the broadest, most encompassing explanation of truth and reality.

Such is his still continuing intellectual legacy, that in the modern era, Alfred North Whitehead declared all of Western philosophy to be a mere footnote to Plato. Inspired by the truths of mathematics, for Plato the best thought was free from sense experience; from the variable, fluctuating nature of the physical world and its phenomena, in an unrelenting search for the One, the true source of "real" knowledge, namely, the Form of Forms.

(b) Gabirol: Ibn Gabirol's Fons Vitae (Fountain of Life) is a good example of Neo-Platonism in Mediaeval Jewish thought. It is a speculative work (in which he refers to only one other author, Plato) that addresses the root of wisdom, which he elaborates through a series of steps: from knowledge of matter and form, through knowledge of the will, to the science of the First Essence.

Everything outside of the creator (the First Essence) consists of varying combinations of matter and form (the 'universal substance'), with simple (pure) substance being superior to compound substance, in a descending series down to the (least pure) corporeal things of experience.

(c) Augustine: Though he was a theologian (perhaps the greatest in the history of post - Apostolic Christianity) and not a philosopher as such, Augustine (Bishop of Hippo) was a keen admirer of Plato and made frequent reference to him in especially his City of God.

Augustine's thought is wide-ranging. As Platonic thinker he acknowledges the importance of and uses rational argument in his theology. Likewise, his central concern is with the One, the Immutable source of everything - based on the need for the kind of certainty that a deep inner knowledge and experience of God and the Soul provides.

(d) Descartes: Descartes' cogito ergo sum philosophy focuses on an empyrean world of innate, self-evident ideas. Though he distrusted the senses throughout his work, he does provide for the corporeal world of things (res extensa). This is to be logically explained following the rules of mathematics (for him the only true example of certain human knowledge), and rejecting any belief based merely on 'custom and example.'

(e) Popper: Karl Popper's theory of science is rooted in a purist (empyrean) approach to knowledge. He proposes a logical, deductive structure for the sciences as the only certain way to achieve truth. His system is based on the idea that all scientific theories are flawed, and that there is no external criterion of truth. He therefore promotes the ideal of aiming (through his principle of 'falsification') to achieve the best possible, unflawed, scientific theory of phenomena of interest to the scientist.

His foundational orientation is manifested in his support for objective knowledge provided by his 'logical theory of truth'; an approach of 'truth by approximation' that deliberately attempts to search for weaknesses in scientific theories through consistent application of the falsification principle. Experience or observation, although important for providing the empirical component of scientific truth, should never be the arbiter of truth. For Popper, the methodological purist (metatype I) and Kantian philosopher, all truth is theory-laden.

\subsubsection{Type II: Aristotle, Maimonides, Aquinas, Hume and Lakatos}

(a) Aristotle: Aristotle may be regarded as the first 'scientific' philosopher among the ancient Greeks. Contrary to Plato 
(his teacher), Aristotle's works are characterized by a systematic classification of the objects and phenomena of nature.

Aristotle's empiricist orientation, and emphasis on the truth provided by the senses, is a predominant feature of his work. His desire was to provide the concepts and cognitive apparatus to achieve precise, empirically supported knowledge in the microscopic style characteristic of modern science. His emphasis on empirical experience and his delight in the senses, especially of sight, is, for instance, prominent in the Metaphysics. For Aristotle experience is as important as theory, and in no way inferior to the latter.

(b) Maimonides: This thinker, still regarded as the pre-eminent Jewish philosopher, is of the view that one should only believe what can be grasped with the intellect or perceived by the senses. His Guide of the Perplexed is aimed at educated Jews who are religious believers with a good background in the sciences (physics, mathematics), but who experience conflict between their faith and the principles of reason. Moses Maimonides is the archetypal Aristotelian who preceded his Christian counterpart, Thomas Aquinas, by almost a century.

(c) Aquinas: Thomas Aquinas is the great systematic (Aristotelian), theologian of Christianity. His main stance was that human knowledge must start with the 'effects' of God, namely the 'finite world' and strive to reach God in this way.

Using Aristotle's concepts of substance, form, matter, act and potency, Aquinas developed a multi-tiered, causal, system that defines God as the first cause. His empiricist epistemology holds that knowledge of God must begin with sense experience and attain to God through rational thought, hence his well-known two-tier structure of nature and grace.

(d) Hume: David Hume, who is generally regarded as the leading philosopher of (British) Empiricism, is known for his disavowal of metaphysics (type I) and especially the Cartesian philosophy of disembodied, 'innate ideas.'

For Hume, the essence of the mind is unknown, and its powers can only be determined by way of careful observation and experiment, such as in the natural sciences. He emphasizes the view that one cannot go beyond experience, even in attempts to formulate universal principles.

(e) Lakatos: Imre Lakatos proposes an approach to scientific knowledge, which he calls 'research programs.' A research program consists of a hard core of main hypotheses (conjectures) and a flexible outer belt of secondary hypotheses and propositions that are more likely to change and be modified over time in scientific investigations.

In contrast to Popper's focus on logical purity, a research program contains sets of hypotheses that are to be assessed by their ability to predict new scientific observations. Lakatos prefers an objectivist-empiricist scheme of scientific research, following a realist conception of truth.

\subsubsection{Type III: Protagoras, Halevi, Luther, Nietzsche and Kuhn}

(a) Protagoras: Protagoras' thought is an early and distinctive example of the narrative-interpretive approach to truth. Contrary to the more impersonal, objectivist, philosophies of Plato and Aristotle, Protagoras' thought is the prototypical example of a pragmatic epistemology combined with an optimistic humanism, with his now famous credo of "Man is the measure of all things."

He was not a systematic thinker attempting to build a theoretical foundation, which is typical of type I and II realms of thought, but a nominalist who viewed human conduct as based only on experience.

(b) Halevi: Halevi's Kitab al Khazari is essentially a defence as well as praise of the Jewish religion and way of life, in the narrative-poetic (type III) modality of mind.

Although he accepted the importance of reason, overall, Judah Halevi had a negative attitude toward philosophy because it reduces God to an impersonal force. This approach has much in common with the Islamic thinker, Al-Ghazali, from whom he derived his inspiration.

(c) Luther: In contrast to the objectivist nature of the thought of Augustine and Aquinas, Martin Luther emphasizes the personal, I - Thou, relationship with God, in the subjectivist-empiricist orientation of mind. It is a relationship based on faith, not on scholastic reasoning.

Luther wanted everything as non-rational, non-legal as possible (contra types I and II), and even as a young man preferred the more personal (type III) approach to theology, rather than a grand, objectivist intellectual structure, typical of scholasticism (reaching back to Aquinas, and even further, to Aristotle).

(d) Nietzsche: Friedrich Nietzsche is the proponent of a philosophy of 'self-overcoming' and of the 'trans-valuation of all values.' He is widely recognized as the modern intellectual debunker (type III mode) par excellence. Nietzsche relentlessly attacks all objectivist-empyrean (metaphysical) thought; thus, any 'system' or edifice of ideas, especially those pretending to be the final word.

His thought is essentially two-fold. It consists, firstly, of repeated and devastating critiques of objectivist thought with its pretence of attaining a purified, static, truth, and, secondly, of a passionate promotion and celebration of life as the Will to Power. 
(e) Kuhn: Kuhn is the critical, unmasking philosopher of science, in the subjectivist-empiricist tradition. What Kuhn mainly intended doing, was to overturn the typical, naïve, account of science as a fully rational and logical undertaking that unfolds in a cumulative and linear way.

His historicist account of the growth of scientific knowledge is opposed to the impersonal, objectivist account of Popper (the type I, metaphysical philosopher of science). He favors an interpretive approach, admitting the importance in his thought of the sociology and social psychology of scientists.

\subsubsection{Type IV: Plato, Pakuda, Calvin, Marx and Feyerabend}

(a) Plato: Plato's aim was to provide a theory of society according to which the Greek city-state could be transformed and turned into a perfect community; a state (polis) where the good of the whole could be achieved according to a strict demarcation of the roles and duties of each class of citizens.

From Plato's account of the ideal (best) society his engagement in the subjectivist-empyrean (type IV) mode of thought, as well as in political praxis (acting as political consultant to king Dion of Syracuse), is clearly evident. In his Seventh Letter he even expresses his desire to be more than a man 'of mere words.'

(b) Pakuda: Ibn Pakuda is the author of the first treatise on ethics in Judaism, entitled Duties of the Heart. Together with Guide of the Perplexed (Maimonides) and Khuzari (Halevi), it became one of the most celebrated works in Judaism.

The work presents a detailed exposition of a range of different ethical imperatives, according to which the Jewish faithful should think and act. Pakuda distinguishes between 'duties of the limb (mere lip service), and 'duties of the heart.' His explicit aim was to promote the latter as being the true wisdom and faith for living the religious life.

(c) Calvin: Jean Calvin was the influential reformer and organizer of Protestantism. Known among Roman Catholics as the 'Pope of Geneva', and among admiring colleagues as the 'Theologian' his type IV orientation is strongly evident in his work and deeds. His aim was to promote God's majesty, power and kingdom on earth. In the process he also compares himself to the biblical ruler, King David.

(d) Marx: Karl Marx desired to transform the world in a revolutionary manner, into a classless society. His ideology of Communism had wide impact and serves as a major example of the subjectivist-empyrean orientation in modern thought.

The Communist Manifesto contains Marx's ideas for bringing about a social revolution in which the proletariat (the poor, working class) are to overthrow and replace the bourgeoisie (capitalists and property-owners). In true subjectivistempyrean (type IV) mode, for Marx it was more important to change history than understanding it.

(e) Feyerabend: Paul Feyerabend is the subjectivist-empiricist (type III) critic of conventional (Popperian) philosophy of science. Later on, especially with his Science in a Free Society, he adopted a strong ideological (type IV) approach. His aim was to promote a removal of the scientists from their central position of influence in society.

\section{Science and Religion in Historical Perspective}

This section approaches the field of science-and-religion (hereafter also referred to as: S-R) from a broad historical point of view. It attempts to show that the often closely intertwined scientific, religious and philosophical character of its discourse is anchored in the continuing interplay of basic and age-old modalities of human thought. (Pietersen, 2011; Pietersen, 2014).

The endeavours of science and of religion are central to human life. Although reason (manifested in the achievements of modern science) and revelation, or faith, has, since the Enlightenment, increasingly become separated, their fundamental co-existence as ineradicable dimensions of human nature and of culture continues.

Classical Greek thought (Jaeger, 1947) presents a striking example of the ebb and flow of these basic powers of the mind; of the close and dynamic interconnectedness of archetypal orientations. These may, in one sense, be described as the Impersonal (reflected in the search for abstract principles and laws of science and of metaphysics) and the Personal (reflected in narratives of divinities and gods in the world).

They operate in pre-Socratic thought, for instance, through varying combinations and sequences of philosophy and theology; of objectivist and subjectivist mixes in the early Greek mind. But, passim Kant, like oil and water they never really mix (Kant, 1960/1794: 12). Poetry (and religious prose) may have its metaphysical moments; metaphysics may be rendered in poetical or quasi-poetical prose (e.g., Plato's dialogues), but poetry is not metaphysics, and vice versa. Similarly (and in conformity with the meta-theoretical stance of the present work and its predecessors), science is not religion (though, for some, it may become so, or treated as such); religion is not science (though many theologians - such as Aquinas and Harnack - have attempted to explain its beliefs and doctrines from the perspective of the scientific 
modality of mind). The fact is that these domains speak different languages; reflect different realms of experience and understanding, and account in different ways for the world that we live in and of which we are part.

Attempts to amalgamate or go beyond these modalities of knowing and being do not succeed. Such, for example, may be observed about the, otherwise stimulating, ideas of Jan Smuts and Teilhard de Chardin (see further on). In these cases the waters are muddied, by either describing the personal in terms of the impersonal, or the impersonal in terms of the personal, and so (in the present author's view) end up as examples of question-begging intellectual 'splicing.'

Thus, the bifurcation of the impersonal and the personal (as well as of empirical and empyrean modalities) is at the root of ancient as well as modern attempts to reconcile faith and reason, religion and science. In a fundamental sense they should be viewed as inseparable, yet separate modes of being and activity - each of which provides meaning to our existence (see Figure 6 below). In the religious sphere this is well-expressed by John Paul II in the opening lines of his encyclical, Fides et Ratio (1998): "Faith and reason are like two wings on which the human spirit rises to the contemplation of truth." (John Paul II, 1998).

Figure 6: Basic modalities of mind

\begin{tabular}{|l|l|l|}
\hline & Impersonal & Personal \\
\hline Worldly & Science (type II) & Poetry (type III) \\
\hline Other-Worldly & Metaphysics(type I) & Religion (type IV) \\
\hline
\end{tabular}

\subsection{A brief historical review}

As far as the topic of the relationship between science and religion is concerned, one may conveniently start with its early manifestation in the thought of the ancient (pre-Socratic) Greeks.

The first point to note is that, contrary to the Jewish (and later on also Christian) religion, the divinities of the ancient Greeks were part of and operated inside the world of nature (partly also a recurring theme through panentheistic and process theological tendencies in the modern S-R literature). In contrast to the Hebrew belief in the world as the free creation of God (the Logos) who: "... is stationed outside the world and brings that world into existence by his own personal fiat [the] Greek gods are stationed inside the world; they are descended from Heaven and Earth, the two greatest and most exalted parts of the universe; and they are generated by the mighty power of Eros, who likewise belongs within the world as an all-engendering primitive force." (Jaeger, 1947: 16).

In the ancient Greek mind the intellectual and religious dimensions of life (reflecting both objectivist and subjectivist modalities in the present context) were, in varying degrees, enmeshed in a way that, contrary to the modern worldview, cannot easily be separated. Jaeger observes: "Taking the natural world as their starting-point, they develop the idea of some highest principle ....and then proceed to assert of it that 'this must be the Divine'." (Jaeger, 1947: 31). This represents a shift from the arche (rule) of the Divine; i.e., the principle (idea; force) of the Divine Hesiodic family of gods that rule everything on earth, to the divinity of the ruling rational Principle, namely, the divine Principle of the first philosophers. But note that philosophy and religion (or S-R in its modern context) is still closely held together in the minds of the early Greek thinkers.

It is interesting to observe the existence of pendulum-swings between the rational and religious content of ancient Greek thought. Meta-theoretically, it must be stated that this also highlights the problem of mixing the personal (namely, mythical Greek divinities) with the first attempts of philosophy to achieve a rational (impersonal) understanding of nature. Following the renowned German classicist, Werner Jaeger (1947), this recurring phenomenon in pre-Socratic thought may briefly be sketched, as follows:

$>$ In the cosmogony of Hesiod, who saw the divine everywhere in the physical elements and forces of nature, an underlying desire to develop a rational (objectivist) scheme of the origins of the gods can be detected: "...a type of causal thinking unmistakably rational in the consistency with which it is carried out, even though it takes the form of myth" (Jaeger, 1947: 12);

$>$ Thales is known for his assertion that 'everything is full of gods,' meaning: "...everything is full of mysterious living forces; the distinction between animate and inanimate nature has no foundation in fact; everything has a soul" (Jaeger, 1947: 21);

> Parmenides' philosophy of one reality and truth that admits no change, an important influence on Plato, is presented in the form of a poem, in which: "... he seeks to proclaim the 'truth' (aletheia) which he has learned from the mouth of the goddess herself, and the whole body of his poem professes to be her direct address to him" (Jaeger, 1947: 94); 
> Heraclitus, in turn, is known for his philosophy of perpetual flux and change, which he relates to a divine cosmic law operating in the world: "...This one thing that keeps asserting itself in struggle and in change is what Heraclitus calls God" (Jaeger, 1947: 119);

> The Ionian philosophy of nature of Empedocles (regarded as an early progenitor of natural science) is similarly presented in terms of mythical religious figures, referring to: "...the four principles or roots of all things as gods, and names them Zeus, Hera, Aidoneus, and Nestis" (Jaeger, 1947: 137);

> Anaxagoras, for whom the sun was a mere 'glowing stone,' tries to find a place for mind in his physical theory of the world and argues that, because mind is not a diverse mix of elements such as the physical world consists of, it must be the divine in us: "...the Divine is Pure reason." (Jaeger, 1947: 164).

Next, some notable figures in later periods of history may be considered for their relevance to the S-R field. Roger Bacon, a contemporary of Thomas Aquinas, was convinced that the best source of certain knowledge is senseexperience; knowledge which is to be gained through experimenting with the objects and phenomena of nature. Thus, the mind becomes satisfied that a fire burns, not by propositional reasoning or argument, but by actually putting one's hand or some 'combustible thing' into it. (Bacon, 1268: 371).

Four hundred and seventy one years later David Hume echoes this Ionian sentiment, by stating that we cannot form any idea or concept of what the taste of a pineapple is, until we have actually tasted one (Pietersen, 2011: 111). However, the difference is that for Hume sense-perception was the only reliable source or basis of truth and of knowledge of the world, whilst Roger Bacon, following the Scholastics, acknowledged the truth of argument or reason, as well as the authority of the Church. Given the times that he lived in, Bacon also included the religious dimension of divine inspiration. Yet, he clearly preferred the certitude of experience provided by experiment - the kind of knowledge that 'calms the mind.'

A name that frequently appears in the S-R literature is, of course, that of Galileo Galilei (1564 - 1641). Never doubting the primacy of the church and of faith, he famously observed that 'religion teaches us how to go to heaven; science teaches us how the heaven goes.' His downfall and well-known recantation of his scientific theories which were based on almost unimpeachable empirical measurements and mathematical analysis is, as the historical record shows, largely the result of his own personality and of the intrigues of certain Aristotelian academics and an ambitious priest Drake, 1980: 61), and not of a clash between science and religion as such. In short, in Galileo's time: "...science had been the handmaiden of philosophy, which in turn was the handmaiden of theology. He wished to free science from subservience to philosophy as the historical obstacle to its utility and progress." (Drake, 1980: 90).

For Immanuel Kant (1794) reason (science) and religion must be separated so that: "...the pure religion of reason will rule overall, 'so that God may be all in all."' (Kant, 1960/1794: 112). Thus, it would seem that Kant leaves the door open for supernatural intervention, yet, on the other hand, views religion as being embedded in experience and history and therefore not inside the trustworthy circle of pure reason, so to speak. In the end, for Kant, outside of rational thought about religion in terms of the fundamental moral law (existing objectively as a universal, immutable, super-sensible principle) and the moral disposition (existing and operating within the human as a subjective, inner, basic moral orientation that is conditioned by the Moral Law), there is no room for a faith based on dogma or opinion. Hence, also, no compelling reasons for giving primacy to beliefs based on Church doctrine, enforced by ecclesiastical authority.

In the mid-nineteenth century, with the rising influence of science, and of its establishment as a profession (the designation 'scientist' first came into use at this time), the two spheres became increasingly estranged from one another. The names of Draper and White are oft-quoted examples of thinkers using terms such as 'antagonism,' 'conflict,' (Draper, 1881: viii) and 'warfare,' (White, 1895) to depict the relationship between science and religion.

Draper characterizes this antagonism as a: "...continuation of a struggle that commenced when Christianity began to attain political power..." (Draper, 1881: vii). He also states that he did not include so-called 'moderate' religions in his attack: "...it is not with the moderates but with the extremists that the impartial reader is mainly concerned." (Draper, 1881: xii). Further-on he sings the praises of science, and expresses the view that: "She has never attempted to throw odium or inflict social ruin on any human being." (Draper, 1881: xii). In reaction to this nineteenth century pro-science sentiment, the question for the present-day (post WW II) reader inevitably arises: but what answer, other than mea culpa, can science give to humanity after Hiroshima and Nagasaki?

At the end of the nineteenth century, the historian, Andrew Dickenson White produced his History of the warfare of science with theology in Christendom (White, 1895). In the North American context this work set the tone for much of the S-R debate during the first half of the twentieth century. In a public address he expounded the thesis that: "In all modern history, interference with science in the supposed interest of religion, no matter how conscientious such interference may have been, has resulted in the direst evils both to religion and science, and invariably; and, on the other hand, all untrammelled scientific investigation, no matter how dangerous to religion some of its stages may have seemed for the 
time to be, has invariably resulted in the highest good both of religion and science." (White, 1895: 3).

We now turn to Teilhard de Chardin, Jan Smuts and Alfred North Whitehead, the first two being clear examples, in the present context, of stimulating but eventually unsuccessful attempts to resolve the impersonal-personal antimony in human thought.

For Teilhard de Chardin the pinnacle of a complex process of evolution is what he describes as the 'Omega-point.' In terms of its meta-theoretical significance, de Chardin's thought is confusing. He firstly expresses the view that: "...at the world's Omega, as at its Alpha, lies the Impersonal," (de Chardin, 1959: 258), which is then followed further-on with the statement that: "The Future-Universal could not be anything else but the Hyper-Personal - at the Omega Point." (de Chardin, 1959: 260). His view of the S-R relationship is that the conflict must be resolved by way of a synthesis: "...when we turn towards the summit, towards the totality and the future, we cannot help engaging in religion. Religion and science are the two conjugated faces or phases of one and the same complete act of knowledge..." (de Chardin, 1959: 285). For the celebrated historian of philosophy, Frederick Copleston, de Chardin's thought in the end turns out to be: "...vague impressions and concepts which are not clearly defined. The whole thing, it may be said, is a mixture of science, poetry and religious faith." (Copleston, 1974: 326).

During the early decades of the twentieth century, the South African statesman and scientist-philosopher, Jan Smuts (who coined the term 'holism') engaged in a venture similar to but independently of Teilhard de Chardin. Unlike the latter, Smuts, however, does not include religion or theology in his own grand metaphysical vision and synthesis of the process of evolution, though it is similarly utopian in its main thrust.

For Smuts: "Evolution is nothing but the gradual development and stratification of progressive series of wholes, stretching from the inorganic beginnings to the highest levels of spiritual creation." (Smuts, 1987/1926: v). This is the principle of 'holism,' a process of 'creative synthesis,' a 'universe of whole-making.' (Smuts, 1987/1926: 87).

Again one finds the unfortunate mix of the impersonal and personal dimensions or modalities of mind. By way of example, he states that: "Finally, there emerge the ideal wholes, or Holistic Ideals, or Absolute Values, disengaged and set free from human personality, operating as creative factors on their own account in the upbuilding of a spiritual world. Such are the Ideals of Truth, Beauty and Goodness, which lay the foundations of a new order in the universe." (Smuts, 1987/1926: 107).

Towards the end of his book, however, he reaches the conclusion that: "Personality is the supreme embodiment of Holism both in its individual and its universal tendencies." (Smuts, 1987/1926: 263). Further-on he continues in quasipoetic, almost mystical, fashion with: "Wholeness as free and harmonious self-realization thus sums up the summum bonum of Holism," (Smuts, 1987/1926: 292), and: "Holism, not Spiritualism, is the key to the interpretation of the universe. Mind is not at the beginning but at the end, but Holism is everywhere and all in all." (Smuts, 1987/1926: 335). 59

Finally, he concludes with: "The groaning and travailing of the universe is never aimless or resultless. Its profound labours mean new creation, the slow, painful birth of wholes, of new and higher wholes, and the slow but steady realization of the Good..." (Smuts, 1987/1926: 344).

Here, it must be observed, Smuts smuggles in teleology through the back door. And the struggle between the personal (Smuts' 'poetic' moments; the value he attaches in his scheme, to 'Personality') and the impersonal (an irresistible 'Force', Principle or Process) dimensions of our thinking surfaces again. Rephrasing Copleston, one may remark of Smuts' system that: 'the whole thing is a mixture of Darwinian science and metaphysics, tinged with poetical mysticism.'

In his Religion in the Making, Whitehead argues for a non-personal, metaphysically defensible, religion. In this system God becomes an 'actual entity', the: "...supreme God of rationalized religion." (Whitehead, 1926: 26). But even Whitehead cannot avoid taking note of the dichotomy, namely, of God as the 'impersonal order of the universe', and of God as the 'one person creating the universe.' (Whitehead, 1926: 35).

Another figure often mentioned in the S-R literature, is Albert Einstein, with his now widely (if not exhaustingly) quoted: "...science without religion is lame, religion without science is blind." Einstein, 1982/1954: 46). Einstein, the pantheist, took an essentially Humean position, separating science (the 'is') from religion (the 'ought'). As far as he was concerned, the idea of a personal God is at the root of the conflict between science and religion, and should be dispensed with. He went on to urge 'teachers of religion': "...to have the stature to give up the doctrine of a personal God." Einstein, 1982/1954: 48).

Coming from another direction, the philosopher Mary Midgley (1992) is concerned about what she perceives to be a modern trend to regard science as the source of salvation, with scant regard for humankind's spiritual needs (Midgley, 1992: 2). To the idea that science and religion is in conflict, her pointed response is that it: "...is an extremely odd idea, since it has to mean that they have somewhere been competing for the same job..." (Midgley, 1992: 51). She asks the question, which she suggests be taken seriously by the S-R scholarly community, whether science: "...is in the business 
of providing the faith by which people live. Is it actually in that business?" (Midgley, 1992: 58). She also puts her finger on an important motive of many, especially leading, S-R participants, namely: the "hunger for a unifying pattern," (Midgley, 1995: 22), the urge to bring science and religion under one roof.

For Brooke, (1991: 33) the view that the science and religion relationship is one of conflict is narrow and inappropriate. The history of science shows a much more complex picture, such as, for example in the case of Isaac Newton who also ascribed the operation of the law of gravitation to God. Both Robert Boyle, the chemist, and Albert Einstein applies religious imagery: nature as temple and the scientist as priest by Boyle (Brooke, 1991: 18); while Einstein speaks of the 'temple of science.' (Einstein, 1982/1954: 224).

For many scientists (at least in the seventeenth and eighteenth centuries), the laws of nature reflects the order in the universe created by God. In the philosophy of law this was, for example, also a basic premise in The Institutes of Justinian (535 CE) and, twelve centuries later (in 1758), by William Blackstone in his Commentaries on the Laws of England. (Pietersen, 2011: 220).

Brooke (1991) unfortunately and mistakenly, refers to the burning of Michael Servetus (1511 - 1553) as an example that is reportedly used to portray conflict between religion and science. However, the historical record shows that Servetus suffered the auto-da-fe for his persistent attack on the Christian doctrine of the Trinity, something which greatly aggravated the leading Protestant reformer of the time, John Calvin. Briefly, in an earlier letter to a colleague Calvin openly stated that if Servetus ever set foot in Geneva, he (Calvin) would never allow him to leave alive. And so it turned out to be the case. It was therefore not a clash between science and religion.

Brooke concludes with the surely more reasonable view that the conflict thesis is overdrawn. Science and religion: "...should rather be seen as complex social activities involving different expressions of human concern, the same individuals often participating in both." (Brooke, 1991: 42).

The next section provides a brief overview of a more recent approach to the science and religion relationship, here referred to as the Zygon movement.

\subsection{The Zygon movement}

The pioneering figure in the modern S-R discussion is Ralph Burhoe, a biologist, who strongly advocated the idea of bringing religion into line with the insights and truths of modern science. Hoping to replace the conventional, 'supernatural,' religion, Burhoe enthuses about the possibility of: "...beginning to speak scientifically about both the human spirit and the Holy Spirit. A scientific spirituality is aborning!" (Burhoe, 2005: 808).

In the mid-sixties a journal, ostensibly aiming to promote dialogue between science and religion, was established, and named Zygon: Journal of Religion and Science. Zygon means: "...the yoking or harnessing of a team which must effectively pull together..." (Editor, 2005: 247). This journal, which soon became a primary (but not only) outlet for scholarly publications in the S-R field, had as its main objective: "...the task of reformulating religion for an age of science, not simply analyzing scientifically or historically what has gone on thus far..." (Editor, 2005: 252).

It should therefore be noted that the modern science-and-religion interface or discussion is essentially an ideologydriven enterprise. It is, in the main, a North American reform movement (incentivized by the financial largesse of the Templeton Foundation), which aims to lay the groundwork for and help bring about a new ('non-supernatural') theology for 'a scientific age'. The major scholarly figure in this endeavour is lan Barbour, a physicist who also trained as a minister of religion, more about whom will be said in Part II.

Given the aim of the present series of papers, only a brief sampler from the burgeoning S-R literature will be given in the following paragraphs, to indicate some of the diversity of issues and proposals that are put forward. With few exceptions, almost all contributors share the scientific worldview, and a conviction that the 'way' of science is the prime example to follow. The main group of S-R participants consists of scientists, philosophers and theologians (mostly the former two groups), and of those with a background in one or more of these disciplines (such as the leading S-R figures of Barbour, Polkinghorne, and Peacocke).

One may observe that there is in much of the S-R writing a contradictory tendency (see Peters, 1996: 328, for instance). On the one hand, the palm is offered for friendly dialogue with religion, but at the same time it is also insisted that for religion/theology to be a worthy conversational partner, it should re-think and re-invent itself, so as to become a credible faith in an 'age of science.' In addition, only a few theologians have so far entered the S-R arena, to the dismay of many current members of this scholarly community, especially Arthur Peacocke.

The prevailing and generally optimistic view among S-R participants is, as Ted Peters confidently phrases it, that: "Both scientists and theologians are engaged in a common search for shared understanding." (Peters, 1996: 323). By contrast, there are also those who are less optimistic about the kind of integration of science and religion that many in the 
S-R community aim (or rather hope) for. As one author rather pessimistically concludes: "... while we may no longer have two totally separate realms of discourse, we also have little likelihood of achieving a single integrated intellectual enterprise." (Mooney, 1991: 36).

Some of the more unconventional proposals that appear in Zygon are as follows:

- Discussion of how an artificial intelligence project, namely: 'Cog, a humanoid robot' can be enriched by theology (Foerst, 1998: 91);

- A complexity theory-based approach called 'chaos theology' (Bonting, 1999: 323);

- Based on the phenomenon of ecstatic feelings that often accompanies epileptic seizures, it is concluded that the human brain is a 'God module' (Albright, 2000: 735);

- Discussion of the neurological roots of religious experience, in which Abraham, Moses, Muhammad and Jesus Christ, are portrayed as examples of 'limbic system hyperactivity.' (Joseph, 2001: 105).

In view of the above (and of other concerns in the field) it should perhaps not come as a surprise that a former Templeton prize-winner, the philosopher Michael Ruse (2007), became wholly disillusioned with the field. In a paper in Zygon, he expresses the following criticisms:

> "Article after article, book after book, seems to me to hover between the trivial and the inane" (Ruse, 2007: 579);

> "Fundamental questions about the nature of existence, about God, about the human being (the soul, for instance), about morality, get thin discussions...too often spin wheels, epicycles on epicycles." (Ruse, 2007: 580);

> "Too many people in the science-religion field are simply not properly trained. You cannot write on these things without some real understanding of philosophy and theology." (Ruse, 2007: 580);

$>$ "There is an enthusiasm in the field these days for the notion of emergence...it seems all too clear that by uncritically embracing emergence people are trying on the cheap or on the sly to get spirituality or some such thing out of material things. It can't be done..." (Ruse, 2007: 581).

This section concludes with a summary of agreements and differences (Barbour, 2010: 247 - 264) between leading S-R thinkers, shown in Figures 7 and 8.

Figure 7: Agreement between leading S-R thinkers

\begin{tabular}{|c|}
\hline Barbour \\
\hline Peacocke \\
\hline Polkinghorne \\
\hline
\end{tabular}

(1) critical realism;

(2) holism, emergence, and levels of organization;

(3) human nature (namely: bio-cultural evolution); and

(4) limitations in God's power

Figure 8: Disagreements between leading S-R thinkers

\begin{tabular}{|l|l|l|l|}
\hline Theme & Barbour & Peacocke & Polkinghorne \\
\hline Conceptions of God: & $\begin{array}{l}\text { Dipolar theism } \\
\text { (God's necessary self-limitation) }\end{array}$ & $\begin{array}{l}\text { Panentheism } \\
\text { (God's voluntary self-limitation) }\end{array}$ & $\begin{array}{l}\text { Trinitarian theism } \\
\text { (God's voluntary self-limitation) }\end{array}$ \\
\hline Laws of nature are: & Temporary habits of nature & Immanent in nature & Ordained by God \\
\hline Divine action is: & Two-way interaction & Whole-part constraint & Information input \\
\hline Christ is: & A man responsive to God's call & A new emergent & The incarnate Son \\
\hline
\end{tabular}

\subsection{Summary}

This paper introduced a fundamental theoretical framework that accounts for axiomatic intellectual distinctions in human thought. This was followed by a survey of the S-R literature indicating that reason and faith, science and religion are not necessarily in conflict. The relationship between the two spheres of human existence is much more complex and intertwined, as should, for example, be evident from pre-Socratic Greek thought.

A burgeoning literature, that in various ways seek consonance or even integration of science and religion, has been generated over the past few decades. Most of the S-R writing are science-oriented and usually takes the view that religion/theology has to be 're-written,' to be more suitable to a scientific age. Supernaturalism is not accepted by most S$\mathrm{R}$ participants today. 


\section{References}

Albright, C. R. (2000) The 'God module' and the complexifying brain, Zygon, vol. 35, no. 4, p735.

Bacon, Roger (1268) On experimental science, From: Oliver J. Thatcher, ed., The Library of Original Sources (Milwaukee: University Research Extension Co., 1901), Vol. V: The Early Medieval World, pp. 369-376., from Internet Medieval Source Book. Paul Halsall May 1998.

Barbour, I. G. (2010) John Polkinghorne on three scientist-theologians, Theology and Science, Vol. 8, (3), pp247 - 264.

Bonting, S. L. (1999) Chaos theology: A new approach to the science-theology dialogue, Zygon, vol. 34, no. 2, p323.

Brooke, J. H. (1991) Science and religion: some historical perspectives, New York: Cambridge University Press.

Burhoe, R. W. (2005) True spirituality in the light of the sciences, (paper presented in 1981), Zygon, Vol. 40, (4), p808

Copleston, F. (1974) A history of philosophy, Volume IX: French Revolution to Sartre, Camus and Levi-Strauss, New York: Doubleday.

de Chardin, Pierre Teilhard (1959) The phenomenon of man, New York: Harper Row.

Drake, S (1980) Galileo, London: Oxford University Press.

Draper, J. W. (1881) History of the conflict between religion and science, New York: Appleton.

Editor, (2005)'Hello world': The first editorial, March 1966," Zygon, vol. 40, no. 1, p247, and 252.

Einstein, A. (1982/1954) Ideas and opinions, New York: Crown Publishers.

Foerst, A. (1998) COG, a humanoid robot, and the question of the image of God, Zygon, vol. 33, (1), p91.

Jaeger, W. (1947) The theology of the early Greek philosophers, London: Oxford University Press.

John Paul II (1998) Fides et Ratio, p1.

Joseph, R. (2001) The limbic system and the soul: evolution and the neuro-anatomy of religious experience, Zygon, vol. 36, (1), p105.

Kant, I. (1960/1794) Religion within the limits of reason alone, Translated with an Introduction and Notes by Theodore M Green and Hoyt H Hudson, New York: Harper Torch. p12.

Mooney, C. F. (1991) Theology and science: A new commitment to dialogue, Theological Studies, Vol. 52, 2, p36.

Midgley, M. (1992) Science as salvation, London: Routledge.

Midgley, M. (1995) Visions, secular and sacred, Hastings Center Report, Vol. 25, 5, p22.

Peters, T. (1996) Theology and science: where are we? Zygon: Journal of Religion and Science, Vol. 31, (2), p328 and 323.

Pietersen, H. J. (2011) The Four Types of Knowing -Metaphysical, Scientific, Narrative and Pragmatic: A Meta-Epistemology of Mind, New York: Edwin Mellen Press.

Pietersen, H. J. (2014) The Four Archetypal Orientations of the Mind: Foundational. Experiential, Organizational and Actional, New York: Edwin Mellen Press.

Ruse, M. (2007) My journey in the world of religion-and-science, Zygon, vol. 42, no. 3, p579, 580, 581.

Smuts, J. C. (1987/1926) Holism and evolution, Cape Town: Citadel Press.

White, A. D. (1895) History of the warfare of science with theology in Christendom, Ithaca: Cornell University Press.

Whitehead, A. W. (1926) Religion in the making, Australia: Web Publication by Mountain Man Graphics. 